\title{
1907 空気充填空洞における長方形水流路の圧力損失特性
}

Characteristics of Pressure Loss of Water Flow in Cavity of Rectangle Pipe

$$
\begin{array}{cccc}
\text { ○学 村尾 昌紀（青学大） } & \text { 学 完戸 岳浩（青学大院） } \\
\text { 正 姜 東赫 (青学大) } & \text { 正 横田 和彦（青学大） }
\end{array}
$$

Masanori MURAO, Aoyama Gakuin University, 5-10-1 Fuchinobe, Chuo-ku, Sagamihara

Takahiro SHISHIDO, Graduate School, Aoyama Gakuin University, 5-10-1 Fuchinobe, Chuo-ku, Sagamihara

Donghyuk KANG, Aoyama Gakuin University, 5-10-1 Fuchinobe, Chuo-ku, Sagamihara

Kazuhiko YOKOTA, Aoyama Gakuin University, 5-10-1 Fuchinobe, Chuo-ku, Sagamihara

\begin{abstract}
The pressure loss characteristics were investigated for the water flow with the water and the air cavities in the rectangular duct. The pressure loss coefficients obtained by the experiments were compared with the total loss based on the typical minor losses. The semi-empirical losses of the friction, the sudden expansion, the sudden contraction and the hydraulic jump are considered as the typical minor losses. The semi-empirical total losses show differences of $24-27 \%$ from the experimental ones. For the case with the air cavity, the hydraulic jump loss increases as the Reynolds number increases. At relatively low $\mathrm{Re}$, the loss coefficients with the air cavity become lower than those with the water cavity. On the other hand, at relatively high Re, the ones with the air cavity are almost same as those with the water cavity.
\end{abstract}

Key Words: Cavity Flow, Pressure Loss Coefficient, Hydraulic Jump

\section{1. 諸論}

エネルギ資源の有限性から，省エネルギは常に最重要課 題の一つと見なされてきた，流体輸送において省エネルギ を実現する方法の一つとして，流動損失の低減が挙げられ る. そして流動損失低減法を研究開発する前段階として, 流動損失の把握が重要な課題となる。流動損失のうち摩擦 損失以外の損失は，流路の形状に起因する損失であり局所 損失(minor loss) と呼ばれている．代表的なものとして，急 拡大損失，急縮小損失，ディフューザ損失，ベンド・エル ボ一損失が知られており，半経験的（半理論的）な計算式 が存在する.複雑な形状の流路を含む管路系全体の損失は, 流路を代表的な形状でモデル化し，摩擦損失と各種の局所 損失の和で代用し，補正されたものが用いられ実用的には 一定の効果を上げている。一方で，より複雑な形状の流路 に対して，より予測精度の高い計算法の開発も期待されて おり，様々な形状の流路に対する損失に関する研究も行な われている。

本研究では, 流路途中にキャビティを持つ流路について, その圧力損失特性を実験的に調べることにした。これは, 急桩大流路と急縮小流路の組み合わせと見な寸事が出来る ので，実験の結果と，これらの損失の重ね合わせとを比較 検討して，流路損失予測の精度を検討することにした。

\section{2. 実験装置および実験方法}

実験装置の概略を図 1 に示す，回流水槽となっている. 矩形ダクトはアクリル製で, 断面は一辺 $\mathrm{D}=50 \mathrm{~mm}$ の正方形 ダクトに，幅 $\mathrm{D}=50 \mathrm{~mm}$ ，高さ $2 \mathrm{D}$ ，長さ $20 \mathrm{D}$ のキャビティ 部からなる。キャビティ上流部及び下流部の長さがそれぞ れ 25Dである.キャビティ上部には空気注入口を設け，キ ヤビティに空気を注入する事が出来る様になっている.

キャビティ上流端を $\mathrm{x}=0$ として $\mathrm{x}=-1 \mathrm{D}, 45 \mathrm{D}$ の位置に 圧力測定孔を設け（それぞれ $p_{1}, p_{2}$ とする)，差圧変換機 $\mathrm{PD}-100 \mathrm{GA}$ ((株) 共和電機)によって圧力差を測定した。ポ ンプ回転数をインバータ制御することにより流量を制御し， 流量計 RHStype（大阪フローメーター株式会社）により流 量を計測した。水温は, 温度計 AD-5624（（株）エー・ア ンド・ディー)によって測定した.
本研究では，キャビティに水を満たした場合（以下，水 キャビティ）,キャビティに空気を満たした場合（以下，空

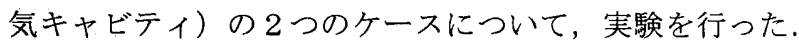

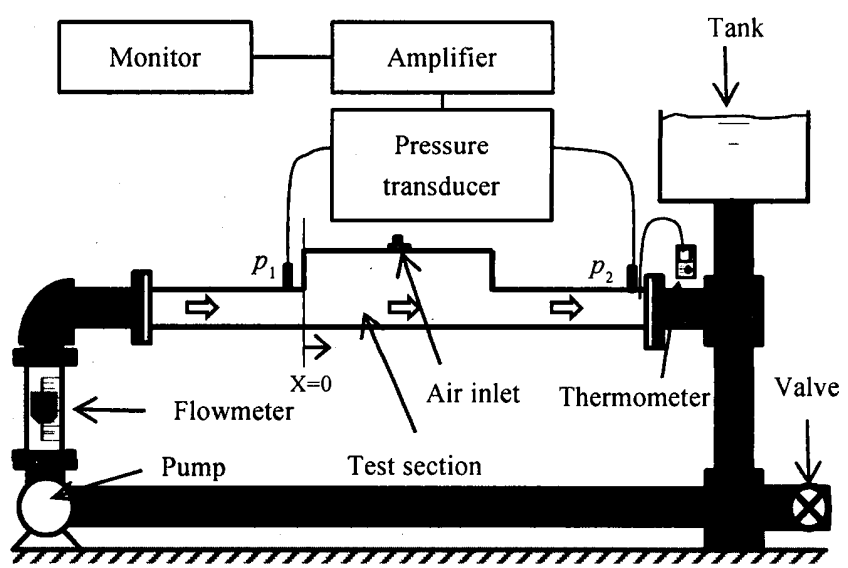

Fig.1 Experimental apparatus

\section{3. 实験結果およびその考察}

以下に用いる,レイノズル数における代表流速及び代表 長さは正方形流路の断面平均流速 $U_{R}$ 及び正方形流路の相 当直径（等価直径） $\mathrm{D}$ として,

で計算した。

$$
R e=U_{R} \mathrm{D} / v
$$

図 2 に, 空気キャビティの場合のキャビティ内の水面挙 動の写真を示す. 図 2(a) は静止状態で, Re の増加に伴って, 図 2(b)のように拡大部 $(\mathrm{x}=0)$ から盛り上がるように流れる (1). $R e=5.0 \times 10^{4}$ を過ぎると(c)のように拡大部から射流と なり，下流で跳水が生じる(2)，この Re では跳水してもキ ヤビティ上部まで水は届いていない，Re が増加して $R e=6.6 \times 10^{4}$ 程度になるとキャビティ部上部に水が届く様に なる. 更に Re が増加すると, キャビティの空気は下流へ 流される様になり，空気量が低くなると共に，射流長さが 短くなる。なお, $R e \geqq 5.8 \times 10^{4}$ 以降では，空気注入または排 出により射流長さが $\mathrm{x}=10 \mathrm{D}$ となるように調節した(d). 


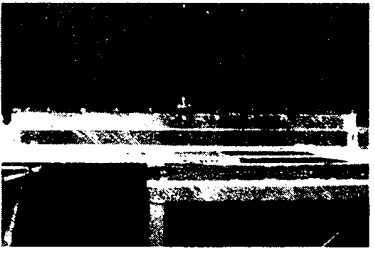

(a) $R e=0$

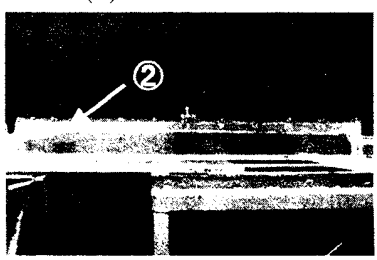

(c) $R e=5.0 \times 10^{4}$

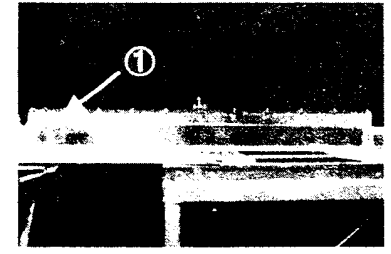

(b) $R e=4.0 \times 10^{4}$

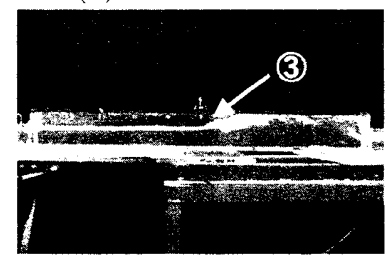

(d) $R e=6.6 \times 10^{-4}$
Fig.2 Test section for air cavity

次に，压力損失特性を調査するために，損失係数を調べ た。損失係数の実験值は，次式で計算した。

$$
\lambda=\left(p_{1}-p_{2}\right) /{ }_{2}^{1} \rho U_{R}^{2}
$$

ここで, 一般的な流体力学の教科書に掲載されている摩 擦損失や各種の局所損失の計算式は, 理論的に導出した数 学的形式に，実用に堪える様に実験によって係数なよ゙の補 正を加えたものであるから，半経験式である，そこで本研 究では,これらに基づいて計算した損失和の值を半経験值 と呼ぶことにする。

キャビティは急拡大部と急縮小部で構成されていること から，局所損失としては，急桩大損失，急縮小損失を考慮 し，これらの和を半経験値とした。また空気キャビティの 場合には更に跳水損失を加えた。これらの損失の詳細につ いては，参考文献(1)および(2)を使用したので，そちらを参 照されたい。

図 3 に，水キャビティにおける圧力損失係数の実験值と 半経験值のグラフを示す. 水キャビティでは, Re の影響は あまり見られない. また実験値と半経験值の差は $24 \sim 27 \%$ であり，流路損失として半経験值を使用する場合にはこの 程度の誤差が含まれている事を考慮する必要がある.また， $R e$ の増加に伴って，損失係数はわずかに減少している．急 拡大損失と急縮小損失は $R e$ によらずほぼ一定と考えられ るので，摩擦損失係数の挙動に起因した為である.

図 4 に, 空気キャビティにおける圧力損失係数の実験値 と半経験值のグラフを示す. 図 4 を見ると, 実験值と半経 験值はほぼ同じ挙動を示している. $R e=5.0 \times 10^{4}$ 付近から $R e=9.7 \times 10^{4}$ 付近までともに右上がりになっている. 図 2 で 説明した様に， $R e>5.0 \times 10^{4}$ でキャビティでは射流と跳水が 生じており，また図 4 での跳水損失の半経験值もこの範囲 で Re が上がるにつれ著しく上昇している，従って，跳水 損失の増加により全体の損失が増加すると考えられる。つ まり高レイノルズ数では, 跳水損失の割合が大きくなる.

図 3 と図 4 を比べると, $R e \leqq 8.0 \times 10^{4}$ では, 空気キャビテ イは水キャビティに対して損失が小さくなっている.一方, $R e \geqq 8.0 \times 10^{4}$ では, 空気キャビティと水キャビティの損失は ほぼ同じくらいである。

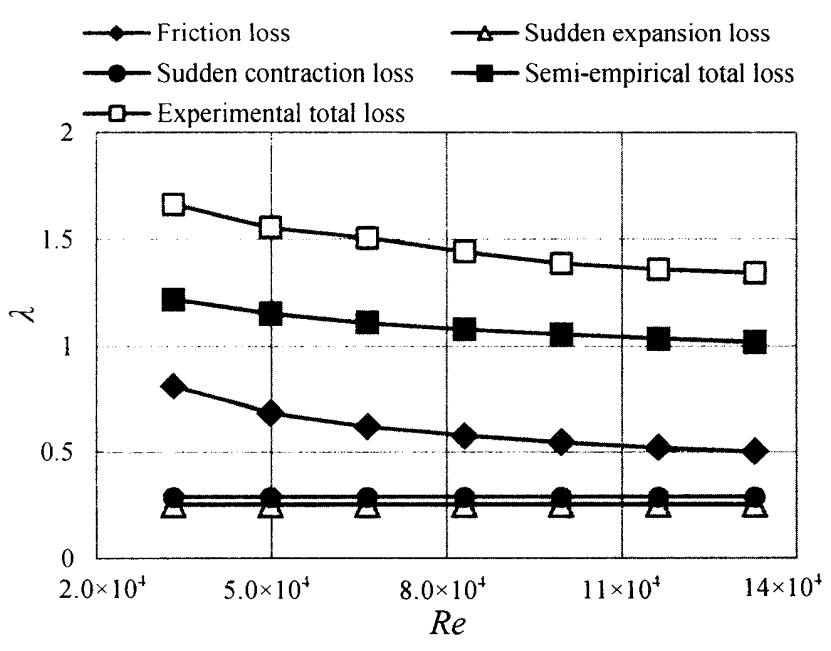

Fig.3 Loss coefficients for water cavity

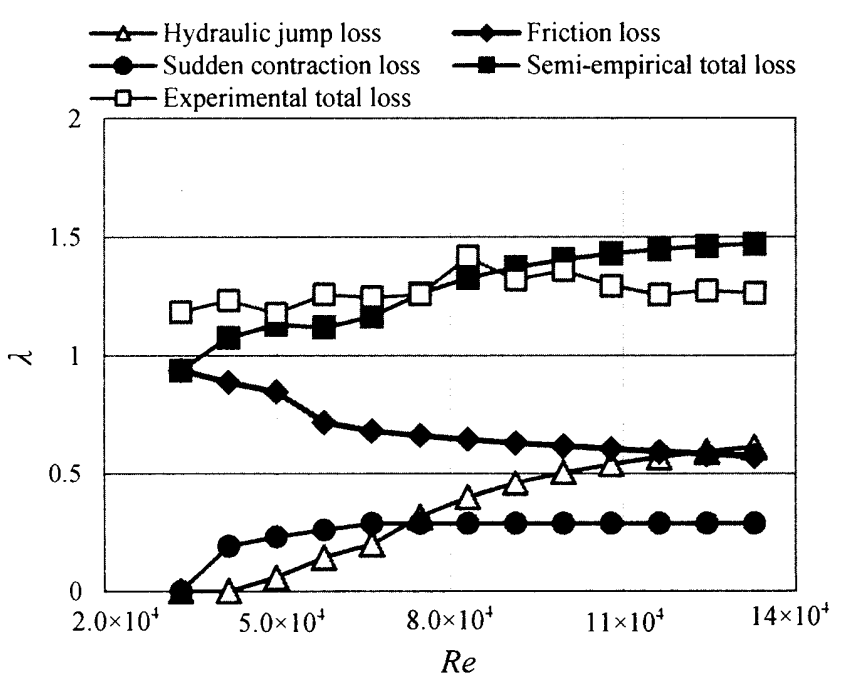

Fig.4 Loss coefficients for air cavity

\section{4. 結詇}

(1)キャビティにおける損失は, 急拡大損失, 急縮小損失 の和とは，25\%程度の差がある。

(2) 空気キャビティでは高レイノルズ数になるにつれ跳水 損失が占める割合が大きくなる.

(3) $R e \leqq 8.0 \times 10^{4}$ では, 空気キャビティの損失は小さくなる が，Re が大きくなると，空気キャビティ及び水キャビ ティの圧力損失はほぼ同じになる。

\section{参考文献}

(1) 佐藤恵一・ほか 3 名, 流れ学 (2009), 朝倉書店

(2) 古屋善正 -ほか 2 名, 流体工学 (1967), 156, 朝倉書店 